\title{
Natural Resources Management Rights in Land Conservation Areas in Coastal Areas and Small Islands Based on Environmental Sustainability
}

\author{
Adonia Ivone Laturette, Rory Jeff Akyuwen, Barzah Latupono, Arman Anwar, La Ode Angga*, Muchtar Anshary Hamid \\ Labetubun
}

Faculty of Law, Pattimura University, Ambon 97233, Indonesia

Corresponding Author Email: laodeangga@yahoo.com

https://doi.org/10.18280/ijsdp.160711

Received: 12 July 2021

Accepted: 7 September 2021

\section{Keywords:}

management rights, natural resources, land conservation areas, environment, coastal and small islands

\begin{abstract}
The coastal area is an area that is very intensively used for human activities, such as the central government area, settlements, industry, ports, aquaculture, agriculture/fishery, tourism, and so on. The existence of these various activities raises the need for space as supporting facilities and infrastructure for each of these activities. This research is a normative legal research. normative legal research is a process to find the rule of law, legal principles, and legal doctrines in order to answer the legal problems faced. The answer obtained from the legal analysis regarding the legal consequences is that the Government does not specifically regulate the regulation of land rights in conservation areas which are determined through the Regional Spatial Planning (RTRW) and Regional Spatial Planning (RZWP3K) so that the legal consequences are uncertainty in law enforcement and also overlapping powers.
\end{abstract}

\section{INTRODUCTION}

Natural resources in the territory of the Unitary State of the Republic of Indonesia must be used wisely and aimed at the greatest prosperity of the people, in accordance with the mandate of Article 33 Paragraph (3) of the 1945 Constitution of the Republic of Indonesia (UUD NRI 1945) as follows [1]:

The earth and water and the natural resources contained therein are controlled by the state and used for the greatest prosperity of the people.

The use of earth, water and natural resources for the greatest prosperity of the people shows that the purpose of their use is solely for the welfare of the people while taking into account the aspect of justice which is indicated by the word "maximum", meaning the results of the use and utilization of earth, water and natural resources. it is not for a particular individual or group but for the people at large.

The discussion about agrarian was initially only focused on the problem of land as the earth's surface. Land includes the surface of the earth that is on land and the surface of the earth that is under water, including sea water [2]. Law Number 5 of 1960 concerning Basic Regulations on Agrarian Principles (UUPA), Article 19 Paragraph (1) says [3]:

That in order to guarantee legal certainty by the government, land registration is carried out throughout the territory of the Republic of Indonesia according to the provisions stipulated in a Government Regulation.

This UUPA is sourced from Article 33 Paragraph (3) of the 1945 Constitution of the Republic of Indonesia. Article 2 Paragraph (2) of the LoGA states that:

The State's Right to Control as referred to in Paragraph (1) of this article authorizes:

a. regulate and administer the designation, use, supply and maintenance of the earth, water and space; b. determine and regulate legal relations between people and the earth, water and space;

c. determine and regulate legal relations between people and legal actions concerning earth, water and space.

Based on the concept of Article 2 paragraph (2) of the LoGA, the notion of being "powered" by the state does not mean owned, but rather the right that authorizes the state to control the above matters. Then, in Article 14 paragraph (1) of the LoGA which states that in the context of implementing socialism in Indonesia, the government has a general plan regarding the supply, designation, and use of the earth, air and space as well as the natural resources contained therein. The authority in other words is the authority to carry out spatial planning.

In carrying out such spatial planning, it is obligatory to pay attention to the principles of environmental management as stated in Article 2 of Law Number 32 Year 2099 concerning Environmental Protection and Management (UPPLH) [4] and spatial planning. With the enactment of Law Number 32 of 2004 concerning Regional Government with the last being replaced by Law Number 23 of 2014 concerning Governance, where each region has full authority over its own region, each regional head has the right to then carry out spatial planning [5].

The coastal area is an area that is very intensively used for human activities, such as a central government area, settlements, industry, ports, aquaculture, agriculture/fishery, tourism, and so on. The existence of these various activities raises the need for space as supporting facilities and infrastructure for each of these activities.

In the coastal area there is also a conservation area, which this conservation area is useful for people's lives in the future. One of the objectives of establishing a conservation area is to protect critical habitats, maintain and improve resource quality, 
protect biodiversity, and protect ecological processes.

Control of land in coastal areas is allowed by applicable laws and regulations starting with Law Number 27 of 2007 concerning Management of Coastal Areas and Small Islands which in its development was amended by Law Number 1 of 2014 concerning Amendments to Law Number 27 Year 2007 concerning Coastal Areas and Islands provides more guarantees of legal certainty for people living in coastal and coastal areas. Not unlike land tenure in mainland areas, land tenure in coastal areas also often experiences problems [6].

In connection with this, a problem arises with the coastal land which is a conservation area. Law Number 1 of 2014 uses the Management of Coastal Areas and Small Islands as a coordination, planning, utilization, control, and control of coastal resources and small islands carried out by Regional Governments, between sectors, between land and marine ecosystems, as well as between science and management to improve people's welfare.

Article 5 Paragraph (1) Regulation of the Minister of Agrarian Affairs and Spatial Planning (Head of the National Land Agency Number 17 of 2016 concerning Land Management in Coastal Areas and Small Islands states as follows:

"The granting of land rights on the coast as referred to in Article 4 letter a can only be granted for buildings that must exist in the coastal area, including:

a) buildings used for defense and security;

b) port or wharf;

c) beach visitor safety guard tower;

d) the place of residence of the customary community or members of the community who have lived in that place for generations; and/or

e) power generation."

In line with that, Article 62 of Maluku Province Regional Regulation Number 1 of 2018 concerning Zoning Plans for Coastal Areas and Small Islands of Maluku Province for 2018 2038 states that:

a. Everyone who uses space from most of the coastal waters and uses part of small islands permanently is required to have a Location Permit

b. The Location Permit as referred to in paragraph (1) becomes the basis for granting a Management Permit.

c. The permit as referred to in paragraph (1) is granted based on the RZWP-3-K.

d. The permit as referred to in paragraph (1) must consider the preservation of coastal ecosystems and small islands, living space and access to small fishermen, traditional fishermen, small fish cultivators, and small salt farmers, national interests, and the right of peaceful passage for foreign ships.

e. Location Permit as referred to in paragraph (1), is granted to:

1) individual Indonesian citizen;

2) corporations based on Indonesian law; and

3) cooperatives formed by the community.

Meanwhile, Article 1 Number 13 of the Maluku Provincial Regulation Number 1 of 2018 stipulates the following:

"Coastal waters are seas connected to land as far as 12 nautical miles measured from coastlines, waters connected to beaches and islands, estuaries, bays, shallow waters, brackish marshes, and lagoons."

The problem that arises then is related to community lands located in coastal areas which are conservation areas, can they continue to be recognized as property rights. The phenomenon in the community that there are ownership rights in mangrove conservation areas, the existence of mangrove forests that have provided many benefits, in fact, many benefits have been obtained, while conservation areas must be maintained and cannot be contested as community property rights. With the description above, the formulation of the problem that will be reviewed in this paper is What is the status of land rights in conservation areas managed by the community?

\section{LITERATURE REVIEW}

The theory used in this writing are:

\subsection{Welfare law state theory}

In this paper, the author uses the Welfare State Theory approach as the Grand Theory [7], supported by the Agrarian Law Politics theory as Applied Theory. The use of state theory as a Grand Theory with the argument and understanding that, in the concept of development, environmental law and agrarian law are an embodiment that applies to the state to create a welfare state (walfare state) in dealing with problems in the field of protection and management of national agrarian resources and the environment, included in the study of this writing.

The theory of the Welfare State in this paper is used to analyze the extent of the involvement of the State in this case the Government, Provincial, Regency and City Governments in the protection and management of natural resources, national agrarian resources and the environment in Indonesia. The State or the Government, the Regency and City Provincial governments, are deemed unable to pay for it to improve the welfare of the community in relation to the protection and management of natural resources (national agrarian) and the environment in Indonesia. That the state or government needs to intervene in the management of natural resources and the environment, including the National Agararia, so that the resources of the people's prosperity are not controlled by a handful of people [8]

In the theory of the welfare state [9] reflecting that the task of the state or government in the implementation of the public interest has become very broad, the possibility of involvement of the interests of the people by the state apparatus is also very broad. In carrying out these tasks, the state administration requires independence, namely the independence to be able to act on its own initiative, especially in solving critical problems that arise where regulations do not yet exist. Due to the extent of the government's functions in the context of a modern legal state or welfare state, of course, the wider role of law in it. The rule of law is a state that places legal power as its power and the implementation of that power in all forms is carried out under the rule of law [10]. Based on this view, all administrators of power in a legal state are based on law. Law is an instrument for controlling state life.

According to John Locke, state power based on law is divided into legislative, executive and federative powers, besides that the state must contain 4 (four) elements, namely as follows:

a. The state aims to guarantee the human rights of citizens.

b. State administrators based on law.

c. There is a separation of state powers in the public interest. 
d. The supremacy of the legislature that supports the interests of the people.

John Locke's view above influenced Montesquieu, the function of the state must be separated into three powers of state power, namely executive, executive and judicial. The positions of these three powers are balanced, one cannot be higher than the other.

In the theory of the welfare state, the goal of the state is seen as an instrument to achieve common goals, namely prosperity and social justice for all Indonesian people [11]. The theory of the welfare state is a combination of the concepts of the state and the welfare state. According to Burkerns [12].

"The state of law (rechtsstaat) is a state that places the law as the basis of its power and exercises that power in all forms which are carried out under the rule of law".

\subsection{Political theory of agrarian law}

According to Urip Santoso (2012: 24) Agrarian Politics is the outline adopted by the State in maintaining, preserving, appropriating, taking benefits, managing and distributing land and other natural resources including the results for the benefit of the people and the State, which for the State of Indonesia is based on Pancasila and the 1945 Constitution of the Republic of Indonesia. Agrarian Politics can be implemented, embodied in a law regulating agrarian affairs which contains all agrarian principles, principles, and issues in outline, equipped with implementing regulations. Thus, there is a close relationship between politics and law.

Understanding Legal Politics relates to the choice to determine legal rules in accordance with the ideology of the ruler. The legal politics that led to the birth of the UUPA revolves around two levels. First, to realize a uniform agrarian law throughout the territory of the Republic as a logical consequence of the existence of an independent Republic, with an independent and just legal order. Second, and farmers to realize a community building, in particular, whether farmers, farm workers, etc. with dignity.

Land Law Politics is a government policy in the field of land aimed at the designation and use of the ruler or land owner, the designation of land use to ensure legal protection and improve welfare and encourage economic activity through the enactment of the Land Law and its implementing regulations.

According to the Constitutional Court, the mandate that the state has the right to control the earth, provide water and natural resources, obliges the state to carry out 5 (five) functions, namely, the policy-making function, the management function, the regulatory function, the management function, and the supervisory function. The five functions, according to the Constitutional Court, are a unity. However, in order to effectively provide the greatest prosperity for the people, the state, according to the Constitutional Court in its decision Number 36/PUU-X/2012, should prioritize its management function, namely direct management of natural resources. After that, the state carries out its function as a policy maker, carrying out management, then regulation and supervision [13].

\section{METHODOLOGY}

This research is a normative legal research. normative legal research is a process to find the rule of law, legal principles, and legal doctrines in order to answer the legal issues at hand.
This research mainly examines legal provisions and positive principles that aim to find solutions to legal problems and problems that arise in it, so that the result to be achieved later is to provide a prescription on what should be on the issue raised [14].

\section{RESULTS AND DISCUSSION}

\subsection{Understanding legal consequences}

According to A. Ridwan Halim, legal consequences are all consequences that occur from all legal actions carried out by legal subjects against legal objects or other consequences caused by certain events determined by self-determined law or considered as legal consequences. According to Marwan Mas, a legal act is every act or action of a legal subject that has legal consequences, and the legal consequences are indeed by legal subjects [15]. Legal consequences are the result of an action taken to obtain a consequence of the actions taken by the perpetrator and regulated by law. Actions which are legal actions are actions taken to obtain something as a result of the law.

It is clearer that legal consequences are all consequences that occur from all legal actions carried out by legal subjects against legal objects or other consequences caused by certain events by law that are determined or considered as legal consequences.

\subsection{Legal consequences on the status of land ownership of conservation areas}

Land regulations that implement the LoGA and other laws related to agrarian affairs may be out of sync either vertically or horizontally with the Loga. Synchronization of laws and regulations between sectors is not an easy problem when the ego of sectorism is still strong among institutions that feel they have their respective authorities.

The wealth of coastal resources controlled by the state must be managed in such a way as to realize the welfare of the community, providing benefits for the present generation without compromising the needs of future generations. In general, many people already live in coastal areas and some even have land rights in coastal areas. This then has an impact on changes in coastal ecosystems because the people who live in the area exploit coastal resources. However, there is a negative impact, there is also a positive impact, namely the maintenance of coastal ecosystems because those who live in the area view that this is their life potential.

Before becoming Law Number 23 of 2014 concerning Regional Government, Law Number 32 of 2004 concerning regional authorities to manage resources in marine areas which include:

a. exploration, exploitation, conservation, and management of marine wealth;

b. administrative arrangements;

c. spatial arrangement;

d. law enforcement on regulations issued by the regions or whose authorities have been delegated by the Government

e. participate in security maintenance; and

f. participate in national defense.

The authority to manage resources in the marine area is a maximum of 12 nautical miles measured from the coastline 
towards the high seas and/or towards archipelagic waters for the province and $1 / 3$ of the province's authority area for districts/cities, which is 0-4 miles. After the issuance of Law Number 23 of 2014 concerning Regional Government in lieu of Law Number 32 of 2004, district/city regional governments no longer have the authority to manage marine areas. Local governments only have authority in the field of capture fisheries and aquaculture. Law Number 23 of 2014 Regional Government regulates the management of marine, coastal, and small islands whose division of affairs is left to the provincial government. These matters are related to:

a. Management of marine space up to 12 miles outside of oil and gas;

b. Issuance of permits and utilization of marine space below 12 miles excluding oil and gas; and

c. Empowerment of coastal communities and small islands.

Ownership and control of land in coastal areas is permitted only according to the applicable laws and regulations. The enactment of Law Number 27 of 2007 concerning Management of Coastal Areas and Small Islands which in its development was later replaced by Law Number 1 of 2014 concerning Amendments to Law Number 27 of 2007 concerning Coastal Areas and Small Islands provides more legal certainty for people living in coastal areas. Not unlike land ownership and control in coastal areas, patterns of land tenure and ownership in coastal areas also often experience disputes.

The conception that becomes the basic philosophy of giving gifts is as an instrument of supervision over the community. The granting of a permit can also be interpreted with a limited number of potentials. In general, the permit is a favorable decision, so it cannot be withdrawn or changed at the expense of the interested party [16].

Licensing is not born by itself immediately, but shows things that are supported by the "authority" that has been given to public officials (the government as the implementer of the law). In the end, the government presents Permits by the government to individuals/individuals and legal entities which are carried out through decrees or statutes which then become the realm of state administrative law. Licensing can be interpreted as a form of implementing the regulatory and controlling functions carried out by the government on activities carried out by the community. Forms of licensing include: registration, recommendation, certification, quota determination and permission to do something that usually must have or be obtained by a company or person before being able to carry out an activity or action. By granting a permit, the entrepreneur allows the person requesting it to take certain actions that should not be done in the public interest that requires supervision [17].

Law Number 1 of 2014 concerning Management of Coastal Areas and Small Islands establishes new rules for activating HP3, namely Location Permits and Management Permits. Location Permit to grant a permit to utilize space from part of the coast in accordance with Law Number 1 of 2014 article 17 paragraph (2), which is obliged to consider the preservation of coastal ecosystems and small islands, traditional fishing communities, national interests, peaceful passage for foreign ships and paragraph (3) in a certain area and time. Utilization of technology to utilize the resources of coastal waters and waters of small islands for salt production activities, marine biopharmacology, marine bio, marine, and others as referred to in Article 19 paragraph (1) and paragraph (2) of Law
Number 12014 . With the enactment of the right of location permit and right of management permit, the parties who obtain the permit in accordance with article 18 of Law Number 1 of 2014 must realize the purpose of granting the permit with a maximum period of 2 years since the permit is issued so that is not revoked.

Previously, Law Number 27 of 2007 broadly had three parts to the environment, namely planning, management, and control and control. The planning in question is the Planning for the Management of Coastal Areas and Small Islands carried out in order to harmonize the interests of economic development with the preservation of Coastal Resources and Small Islands and pay attention to the characteristics and uniqueness of the area. Integrated planning is a gradual and programmed effort to utilize Coastal Resources and Small Islands optimally in order to generate sustainable economic benefits for the prosperity of the community. The plan is accompanied by efforts to control the impact of sectoral development that may arise and maintain its resources. Coastal Zone and Small Islands Planning is divided into four stages:

a. strategic plan;

b. zoning plan;

c. management plan; and

d. action plan.

The management in question is the utilization and exploitation of coastal waters and small islands which is carried out through the granting of utilization permits and Water Concession Rights. Coastal (HP-3).

Permits are granted in accordance with the laws and regulations and the authority of each relevant agency. Furthermore, control and control is carried out to encourage the utilization of resources in the Coastal Zone and Small Islands in accordance with the coastal area management plan.

Location Permit is a permit granted to utilize the space of part of the Coastal Waters which includes the sea surface and water column up to the seabed surface within a certain area limit and/or to utilize a portion of small islands. Meanwhile, Management Permit is a permit granted to utilize the resources of Coastal Waters and the waters of small islands. Thus a Location Permit is needed if someone wants to use space from the island or from the waters around it. Meanwhile, if the use of the space is followed by the use of resources (mining, fishing, etc.), the Location Permit must be followed by a Management Permit.

Location Permit is an absolute requirement for a Management Permit if someone wants to use space from some coastal areas or small islands. However, it is mandatory to have a Location Permit that is excluded from the Indigenous Law Community. This means that a group of Indigenous Law Communities can use and manage certain coastal areas or small islands without the need to report or obtain permission from the Regional Government.

In the context of natural resource conservation in Indonesia, it often creates conflicts with local communities who inhabit the conservation area, it appears that conflicts are not possible because the community already has conservation values that must be protected by biodiversity. The argument for conservation in Indonesia is based on rational considerations that are aimed at utilization but not at the use it sees.

According to Satjipto Rahardjo, the law must be built in accordance with the ideals of law and the reality of the society in which the legal values grow [18], because the ideals of the law are the determining direction or guiding star (leitstren) for the creation of the ideals of society through law so that it must 
be imbued with proper legal ideals. that. Gustav Radbruch in Soejono asserts that, legal ideals do not only work as a benchmark that is regulative, namely that which tests whether a law is fair or not, but also as a basic function that is constitutive, namely that which determines that legal ideals will lose their meaning as law [19].

Legal development absolutely must be based on community values so that the law can understand and be accepted by the community, because according to Satjipto Rahardjo the law is for humans and for their welfare, not humans for the law.

Emphasizes the responsive law of conservation according to Nonet and Selznick's responsive law. According to Nonet and Selznick [20], there is a need for a legal and social theory capable of:

a. trengthen legal value nilai

b. Shows alternatives to coercion and suppression.

They developed this theory by comparing three modalities, namely:

a. Repressive law, namely the law as a servant of repressive power;

b. Autonomous law, namely law as an institution that is distinguished and capable of taming repression and protecting the integrity of its own law;

c. Responsive law, namely, the law as a facilitator of the response to social needs and social aspirations.

Therefore, the law that regulates conservation in Indonesia so that there is no prolonged conflict should be in accordance with accommodating the interests of the community in the form of conservation that pays attention to community values.

Regulations based on several theories above require several types of law that are in accordance with the characteristics of society in Indonesia, where the values of wisdom that exist in society can lead to the management of state policies first. The area as the control holder must ensure in deciding what is wrong and violating the rules in the conservation area.

Another thing that was actually found was the overlapping authority of the tumpeng in the conservation area. As is known, related to institutions in the management of national parks, which according to Article 78A of Law Number 1 of 2014 has mandated that conservation areas in coastal areas and small islands include nature reserves and nature conservation areas located in coastal areas and small islands in the form of National Parks/Parks. National Marine Affairs, Wildlife Sanctuaries, etc. are handed over from the Ministry of Forestry to the Ministry of Marine Affairs and Fisheries, but in practice they are still managed by PHKA (KLHK); there is also a conflict between Law Number 26 of 2007 concerning Spatial Planning with Law Number 27 in conjunction with Law Number 1 of 2014 related to the Regional Spatial Plan (RTRW) and the Zoning Plan for Coastal and Small Islands (RZWPPK) where in Article 24 paragraph (1) of Law Number 26 of 2007 concerning Spatial Planning explains that the detailed spatial planning as referred to in Article 14 paragraph (3) letter b is stipulated by regional regulations. The spatial layout referred to includes land space, sea space, and air space, including space within the earth. Meanwhile Article 9 paragraph (5) of Law no. 27 of 2007 in conjunction with Law no. 1 of 2014 Zoning Plans for Coastal Areas and Small Islands are also stipulated through Regional Regulations. The term of the RTRW or RZWP-3-K is valid for 20 (twenty) years and can be reviewed at least every 5 (five) years, Article 9 paragraph (2) of Law No. 27 of 2014 also stipulates that the RZWP-3-K must be harmonized, harmonized, and balanced with the RTRW of the provincial government or the district/city government, this confirms that they do not need to be made in two different legal formats (two Perda). The RTRW and RZWPPK regulate relatively similar matters but at the technical level they must issue two different Regional Regulations. Although it does not cause legal problems, it will cause a budget burden.

Moving on from there, the Maluku Provincial Regulation No. 16 of 2013 concerning the 2013-2033 Maluku Provincial Spatial Plan has existed since 2013 and the Maluku Provincial Regulation Number 1 of 2018 concerning the Zoning Plan for Coastal Areas and Small Islands of Maluku Province in 2013. 2018-2038 but its existence does not have a significant impact. Because the coastal area is a mangrove conservation area as described in the previous sub-chapter, the local government should still be given a permit, both an establishment permit and a business permit

Location permits and coastal area management permits have not yet been regulated as mandated in Article 22C of Law Number 1 of 2014 that the conditions, procedures for granting, revocation, period, extent, and expiration of Location Permits and Management Permits are regulated by Government Regulation. So far, the RPP has not been discussed. As a result, this has led to unclear licensing procedures, unclear division of authority between the center and the regions, as well as investment barriers.

Starting from the discussion above, the legal consequences that will be caused by legal actions. Legal actions can be interpreted as all human things that give rise to rights and obligations. Legal acts are also all actions carried out by legal subjects regulated by law because these consequences can be considered as the will of those who carry out a law.

A legal act that is prohibited by law or an act against the law is an act that causes harm to other parties, and is contrary to existing law. A law of action ultimately leads to a legal consequence. Legal consequences are the result of a legal action.

The implementation of development and/or rights to land in a conservation area is a legal action which in its implementation also creates legal consequences for the parties, in this case the parties are the land owners, the government, and the community. The form of legal consequences in the theory of legal science can be in the form of [20]:

a. the birth and change of a legal situation;

b. birth, change or disappearance of a legal relationship between two or more legal subjects, if the parties have performed their rights and obligations; and

c. the birth of sanctions if an action is taken against the law.

Therefore, legal subjects in terms of building construction will be subject to sanctions in the form of sanctions, sanctions, and criminal sanctions.

Problems with the construction of buildings on the beach about the ownership of land rights certificates and the number of people occupying vacant land on the beach more than 20 (twenty) years earlier. In the case of community ownership of land in conservation areas in the future, the community uses a system of acquiring land rights by accupatio, namely the occupation of land that is not yet owned by someone. Accupatio theory becomes weak and inappropriate when applied to current conditions, due to the increasingly complex social growth of society, encouraging the development of logistical and new ideas and laws, that the state is the owner of the land and land is an object of state power.

Domein's theory which states that all land whose ownership 
cannot be proven, then the land belongs to the State [20]. In addition to the differences in the concept of traditional Indonesian law with western law caused by problems caused by land in the community in terms of obtaining land rights for someone, the problem that also occurs is that people do not attach importance to permits regarding the construction of the buildings they occupy, because they feel they have rights to land. the building through intensive exploitation on land that is considered vacant, without noticing that they are carrying out construction and reclamation and occupying the first land which is a conservation area since.

\subsection{Legal protection for land in conservation areas}

According to Law Number 32 of 2009 concerning amendments to Law Number 32 of 2009 concerning amendments to Law Number 23 of 1997 concerning Environmental Protection and Management (hereinafter abbreviated as UUPLH). Article 1 paragraph (1) provides the understanding that [21]:

"The environment is the spatial unity of all objects, forces, conditions and living things, including humans and their behavior, which affect the life and welfare of humans and other living creatures."

Article 1 paragraph (2) also states that, "Environmental protection and management is a systematic and integrated approach carried out to protect the environment and prevent pollution and/or environmental damage which includes planning, controlling, maintaining, monitoring and controlling. enforce the law".

With coastal and coastal management having management that the management of coastal environmental resources and services through a comprehensive assessment, planning and managing their utilization activities to achieve optimal and sustainable, thus integration in planning in the management of coastal and coastal areas includes 4 (four) aspects, namely [22]:

a. Ecological or territorial integration, including planning areas (not administrative boundaries), coastal areas as the basis for the management of upstream areas and integration between land and sea ecosystems;

b. Sectoral integration, namely between development sectors;

c. The integration of scientific disciplines is a calculation and academic considerations as a policy input;

d. Stakeholder integration, namely management that is the responsibility of the government and the community.

Bagir Manan views control as a function as well as a right, so it is often referred to as a control function or control [23]. In the implementation of supervision, the stages in the management function are interrelated with each other. The integration of these functions requires the coordination of these functions and the need for quality control results as well as the existence of a quality control system and program from the process of carrying out supervisory duties.

Supervision is initially directed entirely to avoid possible deviations or deviations from what is to be achieved. Through supervision, it is hoped that it can help implement the policies that have been set to achieve the planned goals effectively and efficiently. Even through supervision of an activity that is closely related to the incident or evaluation of the extent to which the work has been carried out. Supervision can also detect the extent to which policies are implemented and the extent of deviations that occur in the implementation of work [24].

Based on this understanding, it can be explained that if it is not in accordance with the standards or standards carried out, then there has been a deviation. Supervision of the Implementation of Regional Government, according to Government Regulation Number 12 of 2017 concerning Guidance and Supervision of the Implementation of Regional Government for:

a. Province, implemented by:

1) Minister, for general supervision; and

b. technical minister/head of non-ministerial government agency, for technical supervision;

2) Regency/City, implemented by the governor as the representative of the Central Government for general and technical supervision.

From the problems above, the steps that need to be taken into account in the development of nature protection and conservation are a pattern in the development of conservation areas in Indonesia, considering that historically, community linkages are very strong, namely as follows [25]:

a. Understanding of socio-culture related to traditional environmental patterns needs to be further encouraged considering the very important role of local communities in conservation efforts;

b. The need to quickly capture various real development issues in the field such as the need for development programs that can provide more direct benefits for improving the welfare of fishing communities, improving the environment, and accelerating regional autonomy;

c. Making legal rules and strict sanctions for destruction and policy violators regarding conservation areas;

d. It is necessary to emphasize the RTRW for conservation areas so that conservation areas are maintained. Where the preservation of conservation areas in Indonesia is based on utilization that considers the interests of manufacture;

e. Community participation and conservation area development actors. At present there tends to be a paradigm shift in approach, from top down to bottom up in the spatial planning process that is more democratic and accommodating to all interests. Past experiences have shown that planning that is procedural, normative, and does not accommodate the interests of development actors who are in the process of preparing it, becomes less able to be implemented due to various obstacles in the field. Such plans, apart from being less aspirational, also tend to be illegitimate (recognized), not accepted, and not adhered to in their implementation.

f. One of the many things that have almost been considered in the spatial planning process is that they do not know or know much less the right to participate in negotiating conflict resolutions or aspects of compensation for the consequences of the costs of impacts caused by the implementation of the spatial plan in a good way towards impact on the physical and social environment. Therefore, it is still necessary to consider the need for the existence of an institution for spatial planning for marine, coastal and small islands that is operational, independent, works on a professional basis, and is capable and authorized to 
mediate conflicts and interests between development actors;

g. The development plan needs to be drawn up in an integrated spatial structure between land and sea coastal areas that allows for a link between the two. This plan also determines the leading development sectors which other activity sectors must adjust and support.

\section{CONCLUSION}

The state must be present in the context of its allocation, use and utilization so that the rights to manage natural resources and the environment do not change individually to the detriment of the public interest. The Regional Government does not specifically regulate arrangements related to land rights in conservation areas that are determined through the RTRW and RZWP3K so that the legal consequences are uncertainty in law enforcement and also overlapping authorities.

\section{REFERENCES}

[1] 1945 Constitution of the Republic of Indonesia (UUD NRI 1945). https://www.blog.aksara.org/2011/06/the1945-constitution.html.

[2] Boedi Harsono, Indonesian Agrarian Law (History of the formation of the Basic Agrarian Law, Content and Implementation), Volume I Twelfth Edition, (Jakarta: Djambatan,

2003.

https://perpustakaan.mahkamahagung.go.id/slims/pusat/ index.php? $\mathrm{p}=$ show_detail\&id $=14589 \&$ keywords $=$.

[3] Law Number 5 of 1960 concerning Basic Regulations on Agrarian Principles (UUPA). https://peraturan.bpk.go.id/Home/Details/51310/uu-no5-tahun-1960.

[4] Law Number 32 of 2009 concerning Environmental Protection and Management (UUPPLH-2009). https://referensi.elsam.or.id/2015/04/uu-nomor-32tahun-2009-tentang-perlindungan-dan-pengelolaanlingkungan-hidup-

2/\#: :text=Perlindungan $\% 20$ dan $\% 20$ Pengelolaan $\% 20 \mathrm{Li}$ ngkungan $\% 20$ Hidup $\% 20$ (PPLH) $\% 20$ menurut $\% 20$ UU\% 20no\%2032,meliputi\%20perencanaan $\% 2 \mathrm{C} \% 20$ pemanfa atan $\% 2 \mathrm{C} \% 20$ pengendalian $\% 2 \mathrm{C}$.

[5] Law Number 32 of 2004 concerning Regional Government.

https://peraturan.bpk.go.id/Home/Details/40768/uu-no32-tahun-

2004\#: :text=Dalam\%20UU\%20ini\%20diatur\%20men genai,masing\%2Dmasing\%20mempunyai\%20pemerint ahan\%20daerah.

[6] Law Number 27 of 2007 concerning Management of Coastal Areas and Small Islands. https://peraturan.bpk.go.id/Home/Details/39911/uu-no27-tahun-2007.

[7] Angga, L.O., Latupono, B., Labetubun M.A.H., Fataruba, S. (2020). Application of hawear customary law in the prevention of pollution and environmental damage on the sea coast in southeast Maluku regency. International Journal of Sustainable Development and Planning, 15(5): 767-774. https://doi.org/10.18280/ijsdp.150519
[8] Angga, L.O., Datie, D.R.A., Tuhulele, P., Fataruba, S., Taufiq, I. (2021). Responsibility of manufacturers in waste management of plastic packaged drink products based on law number 18 of 2008 regarding waste management (Case study in Ambon city, Maluku province). International Journal of Sustainable Development and Planning, 16(2): 327-334. https://doi.org/10.18280/ijsdp.160212

[9] Angga, L.O., Saptenno, M.J. (2020). The Formulation of green open spacein the regional regulation of spatial planning of Maluku Province. International Journal of Scientific \& Technology Research, 9(1).

[10] Bethan, S. (2008). Application of Legal Principles in Preserving Environmental Functions in National Industrial Activities an Effort to Save the Environment and Life Between Generations, Bandung 2008. https://perlibatan.setneg.go.id/index.php?p=show_detail \&id $=5255$.

[11] Kansil, C.S.T. (1977). Constitutional Law of the Republic of Indonesia (1). Jakarta: Rineka Cipta. https://Libraaceh.perpusnas.go.id/detail-opac?id=26615.

[12] Aminuddin, Privatization of BUMN Persero, Doctoral Dissertation Program in Law Faculty of Law UNAIR Suranaya University, 1999. http://repository.unair.ac.id/11694/, assessed on June 15, 2021.

[13] Peter Mahmud Marzuki, Legal Research, Jakarta: Fajar nterpratama Offset, 7th Edition 2005. https://r2kn.litbang.kemkes.go.id/handle/123456789/61 857, assessed on June 15, 2021.

[14] Kusumadara. A. (2013). Development of state rights to land: right to control or right to own? Journal of Media Hukum, 20(2). https://Hukum.ub.ac.id/afifahkusumadara/.

[15] Mas, M. (2004). Introduction to Legal Science, Jakarta, Ghalia Indonesia. https://opac.perpusnas.go.id/DetailOpac.aspx?id=58614 8.

[16] Sutedi, A. (2010). Licensing Law in the Public Service Sector. Jakarta: Sinar Graphic. https://opac.perpusnas.go.id/DetailOpac.aspx?id=72228 2

[17] Ten Berge, Introduction to Licensing Law, (Surabaya:Universitas Airlangga, 1992.

[18] Rahardjo, S. (1980). Law and Society. Bandung: Angkasa.

https://perlibatan.mahkamahagung.go.id/slims/pnjakartaselatan/index.php?p=show_detail\&id=1472\&key words $=$.

[19] Sisworo, S.K. (1995). Considering some of the main ideas of various schools of Philosophy of law in their relation and relevance to Indonesian development law. Collection of Speeches by Professors of FH-UNDIP, Semarang.

https://www.semanticscholar.org/paper/Considering-

Some -Point-of-Mind-MiscellaneousSisworo/af074f2e6c643c87259063f52f335cc4a00ee019.

[20] Soeroso, R. (2005). Introduction to Legal Studies. Jakarta: Sinar Graphic. http://lib.ui.ac.id/detail.jsp?id=20135118.

[21] Angga, L.O., Latupono, B., Hamid Labetubun, M.A., Fataruba, S. (2020). Implementation of precautionaryprinciple in gold mine exploitation in Romang island, Southwest Maluku regency by PT. 
Gemala Borneo Utama based on law number 32 year 2009. International Journal of Scientific \& Technology Research, 9(1).

[22] Angga, L.O., Saptenn, M.J. (2019). The formulation of green open space in the regional regulation of spatial planning of Maluku Province. International Journal of Scientific \& Technology Research, 8(10): 3370-3375.

[23] Angga, L.O., Barzah, L., Anshary, H.L.M., Sabri, F. (2020). Implementation of precautionaryprinciple in gold mine exploitation in Romang Island, Southwest Maluku Regency by PT. Gemala borneo utama based on law number 32 year 2009. International Journal of Scientific \& Technology Research, IJSTR, 9(1). http://www.ijstr.org/paper-references.php?ref=IJSTR-
1019-24111.

[24] Angga, L.O., Saptenn, M.J. (2019). The formulation of green open space in the regional regulation of spatial planning of Maluku Province. International Journal Of Scientific \& Technology Research, 8(10).

[25] Abrar Saleng, Mining Law. (2004). Yogyakarta: UII Press (Anggota

IKAPI) https://www.google.com/search?q=Abrar+Saleng+Huk um+Pertambangan+(Yogyakarta\%3A+UII+Press \%2C+ 2004)+(Anggota+IKAPI.\&rlz=1C1GGRV_enID939ID9 39\&oq=Abrar+Saleng+Hukum+Pertambangan++(Yogy akarta\%3A+UII+Press\%2C+2004)+(Anggota+IKAPI.\& aqs $=$ chrome..69i57.1462j0j7 \&sourceid=chrome \&ie=UT F-8, accessed on June 15, 2021. 